\title{
Targeting Low Disease Activity in Elderly-Onset Rheumatoid Arthritis: Current and Future Roles of Biological Disease-Modifying Antirheumatic Drugs
}

\author{
Takahiko Sugihara $^{1} \cdot$ Masayoshi Harigai $^{2}$
}

Published online: 30 January 2016

(c) The Author(s) 2016. This article is published with open access at Springerlink.com

\begin{abstract}
Elderly rheumatoid arthritis (RA) is classified into two clinical subsets, elderly-onset RA (EORA) and younger-onset elderly RA. With the improvement of life expectancy in the general population and advent of the super-aging society, the number of patients with EORA is anticipated to increase. Both large and small joints are affected initially at onset, and individuals with early EORA have higher scores of disease activity and levels of acutephase reactants than those with early younger-onset RA. EORA is a progressive disease similar to younger-onset RA. Tumor necrosis factor (TNF) inhibitors are equally or slightly less effective in elderly patients than in younger patients with RA, and disease duration may have a greater impact on disease outcomes than age. Evidence of nonTNF biological disease-modifying antirheumatic drug use in EORA is limited. TNF inhibitors may not increase the risk for infection in elderly patients any more than methotrexate; however, increasing age is an independent and strong risk factor for serious infections in patients with RA. Treatment choice in patients with EORA is strongly influenced by comorbidities, especially cardiovascular disease, chronic lung disease, and frailty. To prevent progression to irreversible geriatric syndromes, non-frail patients with EORA, who are aging successfully should undergo intensive treatment using the treat-to-target
\end{abstract}

Masayoshi Harigai

harigai.masayoshi@twmu.ac.jp

1 Department of Medicine and Rheumatology, Tokyo Metropolitan Geriatric Hospital, 35-2 Sakae-cho, Itabashi-ku, Tokyo 173-0015, Japan

2 Department of Epidemiology and Pharmacoepidemiology, Institute of Rheumatology, Tokyo Women's Medical University, 10-22 Kawada-cho, Shinjuku-ku, Tokyo 162-0054, Japan strategy, and pre-frail and frail patients with EORA should be treated with the aim of returning to a non-frail or prefrail stage, respectively. An appropriate treatment strategy for EORA and younger-onset elderly RA should be developed in the next decade using a multi-disciplinary approach.

\section{Key Points}

The growing number of patients with elderly-onset rheumatoid arthritis and younger-onset elderly rheumatoid arthritis poses a challenge to the clinical practice of rheumatology in the super-aging societies.

Biological disease-modifying antirheumatic drugs are indispensable in the treatment of patients with elderly-onset rheumatoid arthritis.

An evidence-based treatment strategy for this patient population should be established in the next decade with special emphasis on the benefit-risk balance of various treatments.

\section{Introduction}

Over the past decade, the clinical development and approval of various types of biological disease-modifying antirheumatic drugs (bDMARDs) along with new classification criteria [1] and a novel treatment strategy has brought about tremendous changes in the outcomes of 
treatment for rheumatoid arthritis (RA). Early diagnosis and immediate initiation of treatment with conventional synthetic DMARDs (csDMARDs), primarily methotrexate (MTX), constitute the mainstream treatment for middleaged patients with RA. Treating RA to target is a consensus strategy in this population [2, 3]; prospective cohort studies and randomized controlled trials (RCTs) showed that aiming at remission or low disease activity (LDA) by strategic switching of DMARDs is a realistic and practicable approach in patients with RA [4-7] and conveys better outcomes than routine care [8].

In the treatment of RA with treat-to-target strategy, bDMARDs are indispensable. The European League against Rheumatism (EULAR) Task Force recommended that in patients responding insufficiently to MTX and/or other csDMARDs, with or without glucocorticoids, a bDMARD [tumor necrosis factor (TNF) inhibitor, T-cell costimulation inhibitor or interleukin-6 receptor-blocking monoclonal antibody, and under certain circumstances, anti-B-cell agent] should be commenced [9]. A 2014 update of recommendations on treating RA to target emphasized that the choice of the composite measure of disease activity and the target value is influenced by comorbidities, patient factors, and drug-related risks [3]. Such influencing factors are frequently observed in patients with elderly RA, which makes treatment of this patient population very challenging. In this article, we review the clinical features of elderly-onset RA (EORA), effectiveness and safety of bDMARDs in elderly RA, and obstacles that prevent rheumatologists from providing standard treatment to EORA patients as well as the countermeasures, and discuss priorities for future research in this growing field of rheumatology.

\section{EORA}

\subsection{Definition}

Elderly RA is categorized into two clinical subsets; EORA and younger-onset elderly RA [10]. Onset after 60 years of age is mainly adopted as the classical definition of EORA in the literature. This definition of EORA has been used throughout this review unless otherwise specified, although we recognize that elderly individuals are generally healthier in the current aging society than ever and the definition of elderly-onset should be validated or modified in future.

\subsection{Epidemiology}

Previous epidemiological studies showed a declining trend in the incidence rates of RA in the period 1955-1994 [11].
However, the incidence rate of EORA (age $>64$ years) increased from 1980 to 2000 [12]. Recent epidemiological studies in Minnesota showed an increasing trend in the incidence rates of RA from 1995 to 2007 in women of each age category [13]. The incidence rates of RA in the 1995-2007 period were highest in individuals aged 65-74 years and decreased over the age of 75 years. The cumulative risk of RA rose sharply around 60 years of age [14]. A recent large RA registry in the United States showed that approximately one-fourth of the enrolled patients were diagnosed with EORA after the age of 60 years [15, 16]. In a Swiss prospective observational cohort for early RA and undifferentiated arthritis (disease duration after the first symptom $\leq 1$ year), the age at disease onset had a Gaussian distribution with a single peak between 50 and 60 years and was $\geq 60$ years in $38.2 \%$ of the 592 patients [17]. Because life expectancy has increased in the general population and people aged $\geq 65$ years account for the fastest-growing population in industrialized countries, the number of patients with EORA will definitely increase over the next decade.

\subsection{Clinical Features}

Various investigators have reported the clinical features of EORA. Both large and small joints are affected more frequently initially at onset, and serological tests show equal or slightly lower percentage of positivity of rheumatoid factor (RF) and anti-cyclic citrullinated peptide (anti-CCP) antibody in individuals with early EORA than in those with early younger-onset RA [10, 18-20]. Individuals with early EORA have higher disease activity scores, erythrocyte sedimentation rates, and C-reactive protein levels than early younger-onset RA [10, 18]. An explosive onset of shoulder arthritis, resembling polymyalgia rheumatica (PMR) is observed in 13-23\% of patients with early EORA [10, 18, 19]. Differentiation between anti-CCP antibody-negative EORA with PMR-like onset and PMR can be difficult and requires careful follow-up [21].

\section{Effectiveness of bDMARDs in Elderly RA}

Several large cohort studies (British, Danish, Dutch, Italian, Spanish, and Swiss registries) investigated the association between treatment response and age [22-27]. TNF inhibitors were slightly less or equally effective in reducing disease activity in elderly individuals compared with younger individuals (Table 1). Health assessment questionnaire (HAQ) scores improved less in elderly RA, especially in patients aged $>75$ years $[22,23,26]$. However, the vast majority of these patients had longstanding disease, and the proportions of EORA patients in the study 
Table 1 Influence of age on the treatment response to biological DMARDs

\begin{tabular}{|c|c|c|c|c|}
\hline Study & $\begin{array}{l}\text { Age and disease } \\
\text { duration in the } \\
\text { elderly age group }\end{array}$ & Treatment & Evaluation & Treatment response vs younger age group \\
\hline $\begin{array}{l}\text { Elderly RA } \\
\text { (RCT) [15] }\end{array}$ & $\begin{array}{l}\text { Age (years): } \\
\text { 61-81 } \\
\text { Duration (years): } \\
0.7 \pm 0.7\end{array}$ & $\begin{array}{l}\text { Treatment arms: IFX or } \\
\text { ADA + MTX vs MTX }\end{array}$ & $\begin{array}{l}\text { DAS28, SDAI, } \\
\text { HAQ, X-ray } \\
\text { score }\end{array}$ & Similar improvement in both treatment arms \\
\hline $\begin{array}{l}\text { Elderly RA } \\
\text { (RCT) [28] }\end{array}$ & $\begin{array}{l}\text { Age (years): } \\
\text { median } 71 \\
(65-82) \\
\text { Duration (years): } \\
0.8(0.1-4)\end{array}$ & $\begin{array}{l}\text { Treatment arms: ETN vs } \\
\text { MTX }\end{array}$ & $\begin{array}{l}\text { ACR20, ACR50, } \\
\text { HAQ }\end{array}$ & $\begin{array}{l}\text { Slightly less improvement in disease activity and } \\
\text { physical function in both treatment arms }\end{array}$ \\
\hline $\begin{array}{l}\text { Elderly RA } \\
\text { (RCT) [28] }\end{array}$ & $\begin{array}{l}\text { Age (years): } \\
\text { median } 68 \\
(65-80) \\
\text { Duration (years): } \\
5.4(0.4-19)\end{array}$ & $\begin{array}{l}\text { Treatment arms: } \\
\text { ETN + MTX vs MTX }\end{array}$ & $\begin{array}{l}\text { ACR20, ACR50, } \\
\text { HAQ, X-ray } \\
\text { score }\end{array}$ & Similar improvement in both treatment arms \\
\hline $\begin{array}{l}\text { Elderly RA } \\
\text { (observational } \\
\text { cohort) }[23]\end{array}$ & $\begin{array}{l}\text { Age (years): } \\
\text { mean } 71.7 \\
\text { Duration (years): } \\
10(4.75-19)\end{array}$ & $\begin{array}{l}\text { Treatments: IFX: } 27.5 \% \text {, } \\
\text { ETN: } 40.2 \% \text {, ADA: } 32.3 \%\end{array}$ & $\begin{array}{l}\text { DAS28, HAQ, } \\
\text { drug survival } \\
\text { rate }\end{array}$ & $\begin{array}{l}\text { Slightly less improvement in disease activity and } \\
\text { physical function; similar drug survival rate }\end{array}$ \\
\hline $\begin{array}{l}\text { Elderly RA } \\
\text { (observational } \\
\text { cohort) }[22]\end{array}$ & $\begin{array}{l}\text { Age (years): } \\
\text { median } 71 \\
(67-74) \\
\text { Duration (years): } \\
14.3 \pm 10\end{array}$ & $\begin{array}{l}\text { Treatments: IFX: } 23.2 \% \text {, } \\
\text { ETN: } 42.1 \% \text {, ADA: } 34.8 \%\end{array}$ & $\begin{array}{l}\text { DAS28, HAQ, } \\
\text { drug survival } \\
\text { rate }\end{array}$ & $\begin{array}{l}\text { Similar improvement in disease activity; similar } \\
\text { drug survival rate; less improvement in physical } \\
\text { function, especially in patients aged }>75 \text { years }\end{array}$ \\
\hline Elderly RA [26] & $\begin{array}{l}\text { Age (years): } \\
\text { mean } \\
70.3 \pm 4.1 \\
\text { Duration (years): } \\
10.9 \pm 7.8\end{array}$ & $\begin{array}{l}\text { Treatments: IFX: } 43.1 \% \text {, } \\
\text { ETN: } 26.7 \% \text {, ADA: } 30.2 \%\end{array}$ & $\begin{array}{l}\text { DAS28, HAQ, } \\
\text { Survival rate }\end{array}$ & $\begin{array}{l}\text { Similar improvement in disease activity; less } \\
\text { improvement in physical function; higher } \\
\text { discontinuation rate because of adverse events }\end{array}$ \\
\hline $\begin{array}{l}\text { EORA } \\
\text { (observational } \\
\text { cohort) [17] }\end{array}$ & $\begin{array}{l}\text { Age (years): } \\
\text { mean } \\
68.5 \pm 6.3 \\
\text { Duration (days): } \\
167.2 \pm 94.7\end{array}$ & $\begin{array}{l}\text { Treatments: Initial treatment: } \\
\text { csDMARDs: } 91.2 \% \text {, } \\
\text { glucocorticoids: } 32.8 \% \text {, } \\
\text { switch to biological } \\
\text { DMARDs: } 6.6 \%\end{array}$ & $\begin{array}{l}\text { DAS28, HAQ, } \\
\text { X-ray score }\end{array}$ & $\begin{array}{l}\text { Similar improvement in disease activity and } \\
\text { physical function; similar rate of radiographic } \\
\text { progression }\end{array}$ \\
\hline $\begin{array}{l}\text { Elderly RA } \\
\text { (observational } \\
\text { cohort) }[25]\end{array}$ & $\begin{array}{l}\text { Age (years): } \\
\quad 72 \pm 5 \\
\text { Duration (years): } \\
13 \pm 10\end{array}$ & $\begin{array}{l}\text { Treatments: IFX: } 45 \% \text {, ETN: } \\
29 \% \text {, ADA: } 26 \%\end{array}$ & Drug survival rate & $\begin{array}{l}\text { Higher discontinuation rate because of adverse } \\
\text { events }\end{array}$ \\
\hline $\begin{array}{l}\text { Elderly RA } \\
\text { (observational } \\
\text { cohort) }[32]\end{array}$ & $\begin{array}{l}\text { Age (years): } \\
\text { median } 71 \\
(67-74) \\
\text { Duration (years): } \\
18.5 \\
(11.5-28.5)\end{array}$ & Treatment: TCZ & $\begin{array}{l}\text { DAS28, drug } \\
\text { survival rate }\end{array}$ & $\begin{array}{l}\text { Less improvement in disease activity; similar } \\
\text { discontinuation rate because of adverse events }\end{array}$ \\
\hline $\begin{array}{l}\text { Elderly RA } \\
\text { (RCT) [33] }\end{array}$ & $\begin{array}{l}\text { Age }>65 \text { years } \\
\text { Duration: not } \\
\text { detected }\end{array}$ & Treatment: TOF & $\begin{array}{l}\text { ACR20, ACR50, } \\
\text { ACR70, HAQ, } \\
\text { drug survival } \\
\text { rate }\end{array}$ & $\begin{array}{l}\text { Similar improvement in ACR20 and ACR50 } \\
\text { response; less improvement in ACR70 response } \\
\text { and physical function; higher discontinuation } \\
\text { rate because of adverse events }\end{array}$ \\
\hline
\end{tabular}

$R A$ rheumatoid arthritis, $R C T$ randomized controlled trial, $I F X$ infliximab, $M T X$ methotrexate, $E T N$ etanercept, $A D A$ adalimumab, $T C Z$ tocilizumab, TOF tofacitinib, EORA elderly-onset rheumatoid arthritis, SDAI Simplified Disease Activity Index, DAS28 Disease Activity Score in 28 Joints, HAQ Health Assessment Questionnaire, DMARDs disease-modifying antirheumatic drugs, ACR20 American College of Rheumatology $20 \%$ improvement criteria, ACR50 American College of Rheumatology $50 \%$ improvement criteria, ACR70 American College of Rheumatology $70 \%$ improvement criteria 
populations were not specified. Because chronic inflammation and subsequent joint destruction owing to RA have a negative impact on physical function as well as the development of comorbidities, the effectiveness of treatment in EORA and younger-onset elderly RA should be investigated separately.

Post hoc analyses of RCTs showed efficacy of TNF inhibitors (etanercept, infliximab, or adalimumab) in elderly patients with early RA who were presumably diagnosed with EORA [15, 28, 29]. Combination of a TNF inhibitor and MTX was more effective in improving signs and symptoms of RA and physical function and in reducing joint damage in elderly patients with early RA compared with MTX monotherapy $[15,28]$. In addition, the efficacy was similar across all age groups in contrast to the results of large cohort studies that enrolled patients with longstanding RA. These results indicated that disease duration may have a greater impact on disease outcomes than onset age. Korean observational cohort also showed that disease duration $\geq 10$ years as well as older age ( $\geq 40$ years) was associated with HAQ disability index $>1$, but onset age was not. After stratification of the patients by disease duration, onset age $\geq 60$ years was associated with HAQ disability index $>1$ in patients with disease duration $<10$ years [30].

The evidence for effectiveness of tocilizumab, abatacept, rituximab, and tofacitinib in elderly RA is scarce. In a French registry, $61(27.5 \%)$ of 222 RA patients treated with tocilizumab were aged $\geq 65$ years at treatment initiation. Tocilizumab was less effective in the elderly group [31], and the drug retention rate for tocilizumab and discontinuation rates because of adverse events were similar between the two age groups, i.e., under 65 years and over 65 years [32]. Data on abatacept in elderly RA were not published. Post hoc analyses of RCTs showed tofacitinib to be similarly efficacious in both the elderly and non-elderly groups (Table 1) [33].

Because a substantial number of patients with EORA have comorbidities or health-related problems that preclude them from participating in RCTs, a prospective, multicenter large cohort study is required to evaluate the effectiveness and safety of treatment with bDMARDs in patients with EORA.

\section{Safety of bDMARDs in Elderly Patients with RA}

\subsection{Overall Safety}

Clinical trials and biologic registries identified the characteristics of adverse drug reactions (ADRs) of bDMARDs. The main ADRs common to all bDMARDs in patients with RA in general are systemic disorders and administrationsite conditions, infection and infestations, nervous system disorders, respiratory, thoracic, and mediastinal disorders, and skin and subcutaneous tissue disorders [34-38]. Among these, infection and infestation and thoracic and mediastinal disorders are usually at the top of the list of serious ADRs with high incidence rates in patients receiving bDMARDs. In addition, malignancy, blood and lymphatic system disorders, immune system disorders, and gastrointestinal perforation, although less common, are considerable ADRs during treatment with bDMARDs.

Several studies have reported the overall safety of bDMARDs in elderly patients compared with younger patients. Sub-analyses of RCTs showed comparable incidence rates of adverse events between patients aged $<65$ and $\geq 65$ years [28, 39, 40]. Some observational studies indicated an increased risk for adverse events or infections in elderly patients treated with TNF inhibitors compared with younger patients $[26,41]$, while other studies reported a similar safety profile between the two groups of patients $[22,42]$. Such discrepancies could arise from differences in study design, study population, types of events analyzed, length of observation period, and statistical methods.

\subsection{Risk of Infection in Elderly Patients with RA}

Population-based studies showed that patients with RA are more susceptible to infection compared with non-RA individuals [43-45]. Hazard ratios (HRs) of infection in patients with RA were between 1.45 and 1.83 , depending on the definition of infections [44], and the risk ratio of hospitalized infection in patients with RA or psoriatic arthritis was 2.7 compared with non-RA population [45]. Older age was a significant risk factor of infection or serious infection in patients with RA [43, 46]. A study using health administrative data of people aged $\geq 66$ years in Canada showed that the most frequently occurring events included respiratory infections, herpes zoster, and skin/soft-tissue infections. Higher comorbidity, rural residence, markers of disease severity, history of previous infection, and use of glucocorticoids, TNF inhibitors, and some DMARDs or immunosuppressants were significant risk factors of serious infection [47]. In regard to the risk of serious infection associated with the use of oral glucocorticoids in older patients ( $\geq 65$ years of age) with RA, the current and recent doses have the highest impact on current risk, but doses taken up to 2.5 years ago are also associated with increased current risk [48]. Use of glucocorticoids doubled the incidence rates of serious bacterial infections in Medicare beneficiaries aged $\geq 65$ years with RA, with clear dose-response relationships and more impact during 1-90 days after treatment initiation compared with $>90$ days [49]. These data indicate that infection is the primary concern in elderly patients with RA, who are initiating treatment with bDMARDs. 
Observational studies comparing RA patients who used TNF inhibitors and conventional DMARDs showed increasing age as an independent risk factor for serious infections [50-52]. This was also the case with pneumonia in patients who were given infliximab [34] as well as serious infection in patients given etanercept [38], adalimumab [53], or tocilizumab [54] in the all-cases postmarketing surveillance programs implemented in Japan. Although the crude rate of infection increased markedly with increasing age in the group starting TNF inhibitors and that starting conventional DMARDs, the adjusted HR of the TNF inhibitor group vs the conventional DMARDs group was similar across the age groups [52]. Similarly, no increase in the risk of serious bacterial infections was observed among the initiators of TNF inhibitors in elderly patients with RA compared with initiators of MTX after adjusting for covariates [49]. There is not enough evidence for the safety of non-TNF bDMARDs in elderly patients with RA including EORA. An analysis of the Medicare claims database of patients with RA revealed the comparative risk of hospitalized infection during treatment with various bDMARDs. Patients aged $\geq 65$ years accounted for $\sim 30$ to $50 \%$ of the patient population in this study. The overall incidence rate of hospitalized infection was 15.3/ 100 patient-years. After adjusting for infection risk score and other potential confounders, infliximab (HR 1.39, $95 \%$ CI 1.21-1.53), rituximab (HR 1.36, $95 \%$ CI 1.21-1.53), and etanercept (HR 1.24, $95 \%$ CI 1.07-1.45) users had a significantly higher hazard of hospitalized infection compared with abatacept users [55].

\section{Challenges in Treatment Targeting LDA in Patients with EORA}

In clinical practice, patients with EORA often have age-, RA-, or treatment-related comorbidities, and these conditions strongly influence the treatment choice. Such comorbidities include cardiovascular disease, cerebrovascular disease, interstitial lung disease (ILD), chronic obstructive pulmonary disease, chronic kidney disease, peptic ulcer, diabetes mellitus, anemia, cachexia, cancer, osteoporosis, osteoarthritis, sarcopenia, skin ulceration, depression, cognitive impairment, and infection. As these diseases are multi-factorial and mutually related, the term "multi-morbidity" instead of comorbidity has recently been proposed to describe them [56].

\subsection{Cardiovascular Disease}

Atherosclerosis is a common age-related comorbidity and an important RA-related comorbidity among patients with RA. Various studies have demonstrated the risk of cardiovascular disease in RA populations [57-60]. An observational study of the registry of North America found that coronary artery disease, myocardial infarction, stroke, and hypertension were more common among individuals with EORA (mean disease duration; 5.3 years) compared with disease duration-matched individuals with younger-onset non-elderly RA [16]. Interestingly, a Swedish cohort of early RA showed differential risks for cardiovascular events and mortality through 10 years between patients with RA with disease onset before 65 years and after 65 years of age. In the elderly-onset population ( $>65$ years of age), good disease control in terms of disease activity and physical function reduced cardiovascular event risk, and the use of glucocorticoids resulted in more cardiovascular events and poorer survival [61]. In the nonelderly-onset population ( $\leq 65$ years of age), inadequate control of inflammation and presence of RF or the antiCCP antibody were associated with cardiovascular events. These findings are in line with the report that the risk for myocardial infarction was reduced in middle-aged patients with RA who responded well to TNF inhibitors [62]. According to the EULAR Task Force, patients with RArelated comorbidities such as cardiovascular disease may undergo intensive treatment [3]. This may be the case with EORA, but further investigation is required to establish an appropriate management strategy.

\subsection{ILD}

ILD is an extra-articular manifestation of RA, and is associated with mortality [63, 64]. Existence of ILD should be examined before treating patients with EORA, as the age at the time of diagnosis of RA was a risk factor for the development of ILD in a Mayo Clinic cohort (HR: 1.41 per 10-year increment in age, $95 \%$ CI 1.11-1.79) [64]. This study showed that the risk for death in RA patients with ILD was three times higher than in RA patients without ILD. The median survival after the ILD diagnosis was only 2.6 years. The British Society for Rheumatology Biologics Register also showed that patients with RA-associated ILD were older than those without ILD [65]. A prospective monocentric Japanese registry of EORA (Choju registry of 
rheumatoid arthritis treated with non-biologic diseasemodifying antirheumatic drugs and biologics in elderly patients in Japan [CRANE]; "Choju" is a Japanese word meaning longevity) found that pre-existing ILD was observed in $25(16.6 \%)$ of 151 patients with EORA; RAassociated ILD deteriorated over a relatively short period in 4 of the 25 patients and one patient without pre-existing ILD developed organizing pneumonia and pleuritis. All five patients were receiving csDMARDs and had high disease activity when ILD worsened; $0.5-1 \mathrm{mg} / \mathrm{kg} / \mathrm{day}$ of prednisolone (PSL) was administered, and four patients recovered, but one died of exacerbation of ILD at week 28 of the observation period [66]. The presence of ILD has significant impact on mortality of patients with RA. Respiratory diseases and malignancy were two major causes of death followed by cardiovascular diseases in a large Japanese cohort. Pneumonia and ILD accounted for 50 and $46 \%$ of the respiratory diseases, respectively [67].

Treatment with bDMARDs in RA patients with ILD is challenging. In patients with RA-associated ILD, mortality following treatment with anti-TNF therapy is not higher than that with traditional DMARDs [65]. However, chronic lung diseases including ILD is a well-established risk factor of infection in patients with RA [46, 51]. Rheumatologists sometimes hesitate to use MTX in patients with RA with ILD, and treatment with glucocorticoids is commenced. Coexistence of chronic lung diseases, older age, and concomitant use of glucocorticoids can further increase risk for infection or serious infection. Hence, the benefitrisk balance of bDMARDs in patients with ILD should be evaluated carefully before starting treatment [50, 68].

\subsection{Frailty}

Frailty is a key concept in geriatric medicine and commonly occurs in older adults [69]. The common definition of frailty uses five criteria, which include weight loss (or loss of muscle), slow walking speed, exhaustion (or fatigue), muscle weakness, and low levels of physical activity. Patients are considered frail if three or more of the five criteria are met. Patients with a score of 1 or 2 are considered to be pre-frail, and a score of 0 indicates that the person is robust or not frail [70]. There are differences in the social, psychological, and physical functioning levels of elderly patients among the three stages of frailty [71]. Various chronic diseases including osteoarthritis, pulmonary disease, cardiovascular disease, stroke, chronic kidney disease, sarcopenia (the age-related loss of skeletal muscle mass), depression, and cognitive impairment are major risk factors of frailty [72-74]. Frail individuals are at an increased risk for negative health outcomes such as functional decline, falls, institutionalization, pressure ulcers, delirium, incontinence, malnutrition, and mortality
(Fig. 1). Although the impact of frailty on mortality of elderly patients with RA is unclear, a recent observational study for patients with osteoarthritis showed that frailty and related geriatric syndromes (i.e., disability of daily living, poor morbidity, visual impairment, cognitive impairment, hearing impairment, urinary incontinence, and low social support) enhanced the risk for long-term mortality of elderly patients [75].

Patients with advanced elderly RA are at a higher risk for progression to frailty because they are more likely to have functional decline, depression, cognitive impairment, falls, malnutrition, and polypharmacy [76-81]. To prevent progression to irreversible geriatric syndromes, non-frail patients with EORA, who are aging successfully, should undergo intensive treatment using the treat-to-target strategy, and pre-frail and frail patients with EORA should be treated with the aim of returning to a non-frail or pre-frail stage, respectively (Fig. 1). Physical exercise may be also an important aspect of treatment strategy of EORA to facilitate maintaining functional capacity in daily life because it provided various beneficial effects including increase of muscle strength, maintenance of normal bone mineral density, and reduced risk of cardiovascular disease in patients with non-elderly RA [82-85]. However, treating frail patients is usually difficult and complicated because they commonly have a variety of age-, RA-, and treatmentrelated comorbidities and are prone to progress to an irreversible stage of disability. In addition, physicians should avoid polypharmacy in this clinical setting because a number of potentially inappropriate medications may induce ADR, drug-drug interactions, and nonadherence in older adults and are associated with serious problems such as delirium, gastrointestinal bleeding, falls, and fracture [86-89].

\section{Role of bDMARDs in Treatment Targeting LDA in EORA}

Previous prospective studies showed that patients with EORA had a prognosis as poor as those with younger-onset non-elderly RA in terms of radiographic progression and physical disability [17, 18]. Anti-CCP antibodies, RF, baseline disease activity, baseline erosion score, and HLADR4 positivity were risk factors of joint destruction in patients with EORA [17-19], and these findings are in overall agreement with previous reports of the predictors of joint destruction in non-elderly RA populations [90-93]. Interestingly, no response by EULAR response criteria at week 12 and non-achievement of LDA at week 24 were both strongly associated with progression of joint destruction at 1 year in patients with EORA receiving treatment targeting LDA [66]. Because rapid improvement 
Fig. 1 Various chronic diseases including rheumatoid arthritis (RA) are major risk factors of frailty. Frail individuals are at an increased risk for developing irreversible geriatric syndromes. An important treatment target for patients with elderly-onset rheumatoid arthritis (EORA) is to achieve a non-frail condition. A non-frail condition is a challenging target to achieve in patients with advanced-stage EORA or EORA with severe comorbidities. Preventing progression to irreversible geriatric syndromes may be a major treatment target in these patients

\begin{tabular}{|c|c|}
\hline \multirow[t]{2}{*}{$\begin{array}{l}\text { No-frailty } \\
\text { Successful } \\
\text { aging }\end{array}$} & $\frac{\text { RA }}{\downarrow}$ \\
\hline & $\uparrow$ \\
\hline $\begin{array}{l}\text { Comorbidit } \\
\text { cardiovascular } \\
\text { stroke } \\
\text { chronic kidney } \\
\text { pulmonary dise } \\
\text { osteoarthritis } \\
\text { sarcopenia } \\
\text { depression } \\
\text { cognitive impai }\end{array}$ & $\begin{array}{l}\text { ease } \\
\text { ease } \\
\text { e } \\
\text { ent }\end{array}$ \\
\hline
\end{tabular}

of disease activity by treatment with bDMARDs reduces the risk for joint destruction in patients with poor prognostic features [90, 92, 94, 95], optimal management of EORA requires intensive treatment including bDMARDs with a careful evaluation of risks for serious adverse events, especially serious infections.

Even though previous studies clearly showed that EORA is a progressive disease similar to younger-onset nonelderly RA, increasing age has been found to be a determinant of less intensive RA care in clinical practice [96, 97]. Biological DMARDs were used less frequently in patients with EORA (EORA $25 \%$ vs younger-onset nonelderly RA $33.1 \%$ ), whereas use of glucocorticoids in patients with EORA was slightly higher (EORA $41 \%$ vs younger-onset non-elderly RA $37.6 \%$ ) than that in patients with younger-onset non-elderly RA [16]. A similar observation was reported from a Swiss cohort: bDMARDs were used in $6.6 \%$ of patients with EORA and $14.1 \%$ of patients with younger-onset non-elderly RA; glucocorticoids were used in $68 \%$ of patients with EORA and $25 \%$ of patients with younger-onset non-elderly RA [17]. Intensive therapy with bDMARDs may be avoided under the assumption that it is not required in patients with EORA. Furthermore, older age, comorbidities, patient factors, and treatment-related risks may preclude the intensification of therapy targeting LDA or remission in patients with EORA.

Although remission should be the primary treatment target for early RA, LDA can be an alternative and valid treatment target in patients with early EORA [3]. Our prospective observational study [66] showed that achieving LDA and structural and functional remission were realistic goals for patients with EORA. In this study, we intensified the treatment as scheduled in advance to achieve LDA.
Adherence to the treat-to-target strategy was possible in $83.4 \%$ of the 151 patients at week 24 and in $75.5 \%$ at week 52 , and $32.4 \%$ of the patients were receiving bDMARDs at week 52 .

Combination therapy with a high dose of MTX and low dose of PSL, with or without other csDMARDs is as effective as biological DMARDs plus MTX to prevent disease progression in middle-aged patients with RA. A Dutch treat-to-target cohort with a mean age of 58.6 years showed that $85.5 \%$ of patients who achieved sustained remission were treated with csDMARDs alone. Nevertheless, bDMARDs may have a major role in the treat-to-target strategy of EORA because longstanding use of PSL and a high dose of MTX may be intolerable or may be associated with serious ADRs in elderly patients. PSL is strongly associated with serious infection in the elderly or EORA population [47, 49, 66]. In our EORA cohort (CRANE), the majority of the elderly patients could not receive the maximum dosage of MTX because of renal dysfunction or dose-dependent ADRs of MTX [66]. The average dose of MTX was $8.9 \pm 2.6 \mathrm{mg} / \mathrm{week}$ $(0.17 \pm 0.06 \mathrm{mg} / \mathrm{kg} /$ week, average weight $51.6 \mathrm{~kg})$ in the CRANE cohort. In an American registry, use of MTX is common in patients with EORA; however, the average MTX dose $(11.96 \mathrm{mg} /$ week, average weight $74.6 \mathrm{~kg})$ in the EORA population is lower than that in the younger-onset RA population [16]. Concomitant MTX is associated with improved retention rates of bDMARDs, particularly TNF inhibitors, in the elderly RA Medicare population [98]. Because a low dose of MTX (10 mg/week) plus adalimumab is sufficient to achieve LDA or functional remission [99], this regimen without PSL may be a realistic intensive treatment for EORA. 


\section{Agenda of Future Clinical Research}

We have drafted a preliminary research agenda for current and future roles of bDMARDs in patients with EORA.

- Prospective and multicentric collection of data on the effectiveness and safety of bDMARDs in patients with EORA and younger-onset elderly RA incorporating treatment intensification targeting LDA or remission. The data should be separately evaluated and compared between patients with EORA and younger-onset elderly RA.

- Evaluation of the impact of frailty and multi-morbidity on disease outcomes in patients with EORA or younger-onset elderly RA treated with biologics.

- Determination of treatment targets in patients with EORA and younger-onset elderly RA with optimal benefit-risk balance.

- Analysis of data of patients with elderly RA from ongoing cohort studies of tocilizumab, abatacept, rituximab, or tofacitinib.

- Establishment of treatment strategy for early EORA with comparative assessment of benefit-risk balance across MTX monotherapy, bDMARDs, PSL, and combination therapy of MTX and other csDMARDs.

\section{Conclusion}

The treat-to-target strategy and role of bDMARDs have been established in middle-aged patients with RA. In the next decade, a strategy suitable for patients with EORA or younger-onset elderly RA should be developed because the number of these patients is on the rise. TNF inhibitors are slightly less or equally effective in reducing disease activity in elderly patients with RA than in younger patients, and disease duration may have a greater impact on disease outcomes than age. Achieving LDA and structural and functional remission are realistic goals in patients with relatively early EORA. With regard to safety, observational studies show increasing age as an independent risk factor for serious infections, and infection is the primary concern in elderly patients with RA, who are initiating treatment with bDMARDs. Cardiovascular disease, chronic lung diseases, and frailty are common problems in the treatment of patients with elderly RA. Multi-morbidities, frailty, and treatment-related risks make it difficult to establish a treatment strategy for EORA, but these issues must be resolved using a multi-disciplinary approach to address the ongoing challenge in the super-aging society.
Acknowledgments None.

\section{Compliance with Ethical Standards}

This work was supported by a Grant-in-Aid from the Ministry of Health, Labour and Welfare, Japan to M. Harigai (H26-meneki-shitei21) and research grants from Takeda Pharmaceutical Co., Ltd, Astellas Pharma Inc., and Teijin Pharma Ltd to T. Sugihara. M. Harigai receives consultant fees or honorarium from Abbvie Japan Co., Ltd., Astellas Pharma Inc., Bristol Myers Squibb K.K., Chugai Pharmaceutical Co., Ltd., Eisai Co., Ltd., Mitsubishi Tanabe Pharma Co., Ono Pharmaceuticals, Pfizer Japan Inc., Sanofi-Aventis KK, Santen Pharmaceutical Co., Ltd., Takeda Pharmaceutical Co., Ltd., Teijin Pharma Ltd., and UCB Japan. The Tokyo Women's Medical University receives unrestricted research grants from Ayumi Pharmaceutical Co. and Takeda Pharmaceutical Co., Ltd and pays the salary for M. Harigai using the grants. T. Sugihara has received honoraria from Takeda Pharmaceutical Co. Ltd., Mitsubishi-Tanabe Pharma Co., Chugai Pharmaceutical Co., Ltd., Santen Pharmaceutical Co., Ltd., Astellas Pharma Inc., Bristol Myers Squibb K.K. and Abbvie Japan Co., Ltd.

Open Access This article is distributed under the terms of the Creative Commons Attribution-NonCommercial 4.0 International License (http://creativecommons.org/licenses/by-nc/4.0/), which permits any noncommercial use, distribution, and reproduction in any medium, provided you give appropriate credit to the original author(s) and the source, provide a link to the Creative Commons license, and indicate if changes were made.

\section{References}

1. Aletaha D, Neogi T, Silman AJ, Funovits J, Felson DT, Bingham CO 3rd, et al. 2010 rheumatoid arthritis classification criteria: an American College of Rheumatology/European League Against Rheumatism collaborative initiative. Ann Rheum Dis. 2010;69(9):1580-8.

2. Smolen JS, Aletaha D, Bijlsma JW, Breedveld FC, Boumpas D, Burmester G, et al. Treating rheumatoid arthritis to target: recommendations of an international task force. Ann Rheum Dis. 2010;69(4):631-7.

3. Smolen JS, Breedveld FC, Burmester GR, Bykerk V, Dougados M, Emery P, et al. Treating rheumatoid arthritis to target: 2014 update of the recommendations of an international task force. Ann Rheum Dis. 2015.

4. Vermeer M, Kuper HH, Hoekstra M, Haagsma CJ, Posthumus $\mathrm{MD}$, Brus HL, et al. Implementation of a treat-to-target strategy in very early rheumatoid arthritis: results of the Dutch Rheumatoid Arthritis Monitoring remission induction cohort study. Arthritis Rheum. 2011;63(10):2865-72.

5. Vermeer M, Kuper HH, Bernelot Moens HJ, Hoekstra M, Posthumus MD, van Riel PL, et al. Adherence to a treat-to-target strategy in early rheumatoid arthritis: results of the DREAM remission induction cohort. Arthritis Res Ther. 2012;14(6):R254.

6. Goekoop-Ruiterman YP, de Vries-Bouwstra JK, Allaart CF, van Zeben D, Kerstens PJ, Hazes JM, et al. Comparison of treatment strategies in early rheumatoid arthritis: a randomized trial. Ann Intern Med. 2007;146(6):406-15.

7. Verstappen SM, Jacobs JW, van der Veen MJ, Heurkens AH, Schenk Y, ter Borg EJ, et al. Intensive treatment with methotrexate in early rheumatoid arthritis: aiming for remission. Computer Assisted Management in Early Rheumatoid Arthritis (CAMERA, an open-label strategy trial). Ann Rheum Dis. 2007;66(11):1443-9. 
8. Stoffer MA, Schoels MM, Smolen JS, Aletaha D, Breedveld FC, Burmester G, et al. Evidence for treating rheumatoid arthritis to target: results of a systematic literature search update. Ann Rheum Dis. 2016;75:16-22.

9. Smolen JS, Landewe R, Breedveld FC, Buch M, Burmester G, Dougados M, et al. EULAR recommendations for the management of rheumatoid arthritis with synthetic and biological disease-modifying antirheumatic drugs: 2013 update. Ann Rheum Dis. 2014;73(3):492-509.

10. Deal CL, Meenan RF, Goldenberg DL, Anderson JJ, Sack B, Pastan RS, et al. The clinical features of elderly-onset rheumatoid arthritis: a comparison with younger-onset disease of similar duration. Arthritis Rheum. 1985;28(9):987-94.

11. Doran MF, Pond GR, Crowson CS, O'Fallon WM, Gabriel SE. Trends in incidence and mortality in rheumatoid arthritis in Rochester, Minnesota, over a forty-year period. Arthritis Rheum. 2002;46(3):625-31.

12. Kaipiainen-Seppanen O, Kautiainen H. Declining trend in the incidence of rheumatoid factor-positive rheumatoid arthritis in Finland 1980-2000. J Rheumatol. 2006;33(11):2132-8.

13. Myasoedova E, Crowson CS, Kremers HM, Therneau TM, Gabriel SE. Is the incidence of rheumatoid arthritis rising? Results from Olmsted County, Minnesota, 1955-2007. Arthritis Rheum. 2010;62(6):1576-82.

14. Crowson CS, Matteson EL, Myasoedova E, Michet CJ, Ernste FC, Warrington KJ, et al. The lifetime risk of adult-onset rheumatoid arthritis and other inflammatory autoimmune rheumatic diseases. Arthritis Rheum. 2011;63(3):633-9.

15. Koller MD, Aletaha D, Funovits J, Pangan A, Baker D, Smolen JS. Response of elderly patients with rheumatoid arthritis to methotrexate or TNF inhibitors compared with younger patients. Rheumatology (Oxford). 2009;48(12):1575-80.

16. Tutuncu Z, Reed G, Kremer J, Kavanaugh A. Do patients with older-onset rheumatoid arthritis receive less aggressive treatment? Ann Rheum Dis. 2006;65(9):1226-9.

17. Mueller RB, Kaegi T, Finckh A, Haile SR, Schulze-Koops H, von Kempis J. Is radiographic progression of late-onset rheumatoid arthritis different from young-onset rheumatoid arthritis? Results from the Swiss prospective observational cohort. Rheumatology (Oxford). 2014;53(4):671-7.

18. van der Heijde DM, van Riel PL, van Leeuwen MA, van't Hof MA, van Rijswijk MH, van de Putte LB. Older versus younger onset rheumatoid arthritis: results at onset and after 2 years of a prospective followup study of early rheumatoid arthritis. J Rheumatol. 1991;18(9):1285-9.

19. Pease CT, Bhakta BB, Devlin J, Emery P. Does the age of onset of rheumatoid arthritis influence phenotype? A prospective study of outcome and prognostic factors. Rheumatology (Oxford). 1999;38(3):228-34.

20. Lopez-Hoyos M, Ruiz de Alegria C, Blanco R, Crespo J, Pena M, Rodriguez-Valverde $\mathrm{V}$, et al. Clinical utility of anti-CCP antibodies in the differential diagnosis of elderly-onset rheumatoid arthritis and polymyalgia rheumatica. Rheumatology (Oxford). 2004;43(5):655-7.

21. Caporali R, Montecucco C, Epis O, Bobbio-Pallavicini F, Maio T, Cimmino MA. Presenting features of polymyalgia rheumatica (PMR) and rheumatoid arthritis with PMR-like onset: a prospective study. Ann Rheum Dis. 2001;60(11):1021-4.

22. Genevay S, Finckh A, Ciurea A, Chamot AM, Kyburz D, Gabay C. Tolerance and effectiveness of anti-tumor necrosis factor alpha therapies in elderly patients with rheumatoid arthritis: a population-based cohort study. Arthritis Rheum. 2007;57(4):679-85.

23. Radovits BJ, Kievit W, Fransen J, van de Laar MA, Jansen TL, van Riel PL, et al. Influence of age on the outcome of antitumour necrosis factor alpha therapy in rheumatoid arthritis. Ann Rheum Dis. 2009;68(9):1470-3.
24. Hyrich KL, Watson KD, Silman AJ, Symmons DP. Predictors of response to anti-TNF-alpha therapy among patients with rheumatoid arthritis: results from the British Society for Rheumatology Biologics Register. Rheumatology (Oxford). 2006;45(12):1558-65.

25. Busquets N, Tomero E, Descalzo MA, Ponce A, Ortiz-Santamaria $\mathrm{V}$, Suris $\mathrm{X}$, et al. Age at treatment predicts reason for discontinuation of TNF antagonists: data from the BIOBADASER 2.0 registry. Rheumatology (Oxford). 2011;50(11):1999-2004.

26. Filippini M, Bazzani C, Favalli EG, Marchesoni A, Atzeni F, Sarzi-Puttini P, et al. Efficacy and safety of anti-tumour necrosis factor in elderly patients with rheumatoid arthritis: an observational study. Clin Rev Allergy Immunol. 2010;38(2-3):90-6.

27. Hetland ML, Christensen IJ, Tarp U, Dreyer L, Hansen A, Hansen IT, et al. Direct comparison of treatment responses, remission rates, and drug adherence in patients with rheumatoid arthritis treated with adalimumab, etanercept, or infliximab: results from eight years of surveillance of clinical practice in the nationwide Danish DANBIO registry. Arthritis Rheum. 2010;62(1):22-32.

28. Bathon JM, Fleischmann RM, Van der Heijde D, Tesser JR, Peloso PM, Chon Y, et al. Safety and efficacy of etanercept treatment in elderly subjects with rheumatoid arthritis. J Rheumatol. 2006;33(2):234-43.

29. Fleischmann RM, Baumgartner SW, Tindall EA, Weaver AL, Moreland LW, Schiff MH, et al. Response to etanercept (Enbrel) in elderly patients with rheumatoid arthritis: a retrospective analysis of clinical trial results. J Rheumatol. 2003;30(4):691-6.

30. Cho SK, Sung YK, Choi CB, Cha HS, Choe JY, Chung WT, et al. Do patients with elderly-onset rheumatoid arthritis have severe functional disability? Semin Arthritis Rheum. 2012;42(1):23-31.

31. Pers YM, Fortunet C, Constant E, Lambert J, Godfrin-Valnet M, De Jong A, et al. Predictors of response and remission in a large cohort of rheumatoid arthritis patients treated with tocilizumab in clinical practice. Rheumatology (Oxford). 2014;53(1):76-84.

32. Pers YM, Schaub R, Constant E, Lambert J, Godfrin-Valnet M, Fortunet $\mathrm{C}$, et al. Efficacy and safety of tocilizumab in elderly patients with rheumatoid arthritis. Jt Bone Spine. 2015;82(1):25-30.

33. Curtis JR, Schulze-Koops H, Takiya L, Mebus CA, Terry K, Chew R, et al. Efficacy and safety of tofacitinib in older and younger patients with rheumatoid arthritis. Ann Rheum Dis. 2013;65(Suppl 10):2331.

34. Takeuchi T, Tatsuki Y, Nogami Y, Ishiguro N, Tanaka Y, Yamanaka $\mathrm{H}$, et al. Postmarketing surveillance of the safety profile of infliximab in 5000 Japanese patients with rheumatoid arthritis. Ann Rheum Dis. 2008;67(2):189-94.

35. Koike T, Harigai M, Ishiguro N, Inokuma S, Takei S, Takeuchi T, et al. Safety and effectiveness of adalimumab in Japanese rheumatoid arthritis patients: postmarketing surveillance report of 7740 patients. Mod Rheumatol. 2014;24(3):390-8.

36. Koike T, Harigai M, Inokuma S, Ishiguro N, Ryu J, Takeuchi T, et al. Effectiveness and safety of tocilizumab: postmarketing surveillance of 7901 patients with rheumatoid arthritis in Japan. J Rheumatol. 2014;41(1):15-23.

37. Ramiro S, Gaujoux-Viala C, Nam JL, Smolen JS, Buch M, Gossec L, et al. Safety of synthetic and biological DMARDs: a systematic literature review informing the 2013 update of the EULAR recommendations for management of rheumatoid arthritis. Ann Rheum Dis. 2014;73(3):529-35.

38. Koike T, Harigai M, Inokuma S, Ishiguro N, Ryu J, Takeuchi T, et al. Postmarketing surveillance of safety and effectiveness of etanercept in Japanese patients with rheumatoid arthritis. Mod Rheumatol. 2011;21(4):343-51. 
39. Fleischmann R, Iqbal I. Risk: benefit profile of etanercept in elderly patients with rheumatoid arthritis, ankylosing spondylitis or psoriatic arthritis. Drugs Aging. 2007;24(3):239-54.

40. Fleischmann R, Baumgartner SW, Weisman MH, Liu T, White B, Peloso P. Long term safety of etanercept in elderly subjects with rheumatic diseases. Ann Rheum Dis. 2006;65(3):379-84.

41. Chevillotte-Maillard H, Ornetti P, Mistrih R, Sidot C, Dupuis J, Dellas JA, et al. Survival and safety of treatment with infliximab in the elderly population. Rheumatology (Oxford). 2005;44(5):695-6.

42. Migliore A, Bizzi E, Lagana B, Altomonte L, Zaccari G, Granata $\mathrm{M}$, et al. The safety of anti-TNF agents in the elderly. Int $\mathbf{J}$ Immunopathol Pharmacol. 2009;22(2):415-26.

43. Doran MF, Crowson CS, Pond GR, O'Fallon WM, Gabriel SE. Predictors of infection in rheumatoid arthritis. Arthritis Rheum. 2002;46(9):2294-300.

44. Doran MF, Crowson CS, Pond GR, O'Fallon WM, Gabriel SE. Frequency of infection in patients with rheumatoid arthritis compared with controls: a population-based study. Arthritis Rheum. 2002;46(9):2287-93.

45. Franklin J, Lunt M, Bunn D, Symmons D, Silman A. Risk and predictors of infection leading to hospitalisation in a large primary-care-derived cohort of patients with inflammatory polyarthritis. Ann Rheum Dis. 2007;66(3):308-12.

46. Crowson CS, Hoganson DD, Fitz-Gibbon PD, Matteson EL. Development and validation of a risk score for serious infection in patients with rheumatoid arthritis. Arthritis Rheum. 2012;64(9):2847-55.

47. Widdifield J, Bernatsky S, Paterson JM, Gunraj N, Thorne JC, Pope $\mathrm{J}$, et al. Serious infections in a population-based cohort of 86,039 seniors with rheumatoid arthritis. Arthritis Care Res (Hoboken). 2013;65(3):353-61.

48. Dixon WG, Abrahamowicz M, Beauchamp ME, Ray DW, Bernatsky $S$, Suissa $S$, et al. Immediate and delayed impact of oral glucocorticoid therapy on risk of serious infection in older patients with rheumatoid arthritis: a nested case-control analysis. Ann Rheum Dis. 2012;71(7):1128-33.

49. Schneeweiss S, Setoguchi S, Weinblatt ME, Katz JN, Avorn J, Sax PE, et al. Anti-tumor necrosis factor alpha therapy and the risk of serious bacterial infections in elderly patients with rheumatoid arthritis. Arthritis Rheum. 2007;56(6):1754-64.

50. Komano Y, Tanaka M, Nanki T, Koike R, Sakai R, Kameda H, et al. Incidence and risk factors for serious infection in patients with rheumatoid arthritis treated with tumor necrosis factor inhibitors: a report from the Registry of Japanese Rheumatoid Arthritis Patients for Longterm Safety. J Rheumatol. 2011;38(7):1258-64.

51. Sakai R, Komano Y, Tanaka M, Nanki T, Koike R, Nagasawa H, et al. Time-dependent increased risk for serious infection from continuous use of tumor necrosis factor antagonists over three years in patients with rheumatoid arthritis. Arthritis Care Res (Hoboken). 2012;64(8):1125-34.

52. Galloway JB, Hyrich KL, Mercer LK, Dixon WG, Fu B, Ustianowski AP, et al. Anti-TNF therapy is associated with an increased risk of serious infections in patients with rheumatoid arthritis especially in the first 6 months of treatment: updated results from the British Society for Rheumatology Biologics Register with special emphasis on risks in the elderly. Rheumatology (Oxford). 2011;50(1):124-31.

53. Koike T, Harigai M, Ishiguro N, Inokuma S, Takei S, Takeuchi $\mathrm{T}$, et al. Safety and effectiveness of adalimumab in Japanese rheumatoid arthritis patients: postmarketing surveillance report of the first 3,000 patients. Mod Rheumatol. 2012;22(4):498-508.

54. Koike T, Harigai M, Inokuma S, Ishiguro N, Ryu J, Takeuchi T, et al. Postmarketing surveillance of tocilizumab for rheumatoid arthritis in Japan: interim analysis of 3881 patients. Ann Rheum Dis. 2011;70(12):2148-51.

55. Yun H, Xie F, Delzell E, Chen L, Levitan EB, Lewis JD, et al. Risk of hospitalised infection in rheumatoid arthritis patients receiving biologics following a previous infection while on treatment with anti-TNF therapy. Ann Rheum Dis. 2015;74(6):1065-71.

56. Radner H, Yoshida K, Smolen JS, Solomon DH. Multimorbidity and rheumatic conditions-enhancing the concept of comorbidity. Nat Rev Rheumatol. 2014;10(4):252-6.

57. Maradit-Kremers H, Nicola PJ, Crowson CS, Ballman KV, Gabriel SE. Cardiovascular death in rheumatoid arthritis: a population-based study. Arthritis Rheum. 2005;52(3):722-32.

58. Maradit-Kremers H, Crowson CS, Nicola PJ, Ballman KV, Roger $\mathrm{VL}$, Jacobsen SJ, et al. Increased unrecognized coronary heart disease and sudden deaths in rheumatoid arthritis: a populationbased cohort study. Arthritis Rheum. 2005;52(2):402-11.

59. Liao KP, Solomon DH. Traditional cardiovascular risk factors, inflammation and cardiovascular risk in rheumatoid arthritis. Rheumatology (Oxford). 2013;52(1):45-52.

60. Dixon WG, Symmons DP. What effects might anti-TNFalpha treatment be expected to have on cardiovascular morbidity and mortality in rheumatoid arthritis? A review of the role of TNFalpha in cardiovascular pathophysiology. Ann Rheum Dis. 2007;66(9):1132-6.

61. Ajeganova S, Andersson ML, Frostegard J, Hafstrom I. Disease factors in early rheumatoid arthritis are associated with differential risks for cardiovascular events and mortality depending on age at onset: a 10-year observational cohort study. J Rheumatol. 2013;40(12):1958-66.

62. Dixon WG, Watson KD, Lunt M, Hyrich KL, Silman AJ, Symmons DP. Reduction in the incidence of myocardial infarction in patients with rheumatoid arthritis who respond to anti-tumor necrosis factor alpha therapy: results from the British Society for Rheumatology Biologics Register. Arthritis Rheum. 2007;56(9):2905-12.

63. Young A, Koduri G, Batley M, Kulinskaya E, Gough A, Norton $\mathrm{S}$, et al. Mortality in rheumatoid arthritis increased in the early course of disease, in ischaemic heart disease and in pulmonary fibrosis. Rheumatology (Oxford). 2007;46(2):350-7.

64. Bongartz T, Nannini C, Medina-Velasquez YF, Achenbach SJ, Crowson CS, Ryu JH, et al. Incidence and mortality of interstitial lung disease in rheumatoid arthritis: a population-based study. Arthritis Rheum. 2010;62(6):1583-91.

65. Dixon WG, Hyrich KL, Watson KD, Lunt M, Symmons DP. Influence of anti-TNF therapy on mortality in patients with rheumatoid arthritis-associated interstitial lung disease: results from the British Society for Rheumatology Biologics Register. Ann Rheum Dis. 2010;69(6):1086-91.

66. Sugihara T, Ishizaki T, Hosoya T, Iga S, Yokoyama W, Hirano F, et al. Structural and functional outcomes of a therapeutic strategy targeting low disease activity in patients with elderly-onset rheumatoid arthritis: a prospective cohort study (CRANE). Rheumatology. 2015;54(5):798-807.

67. Nakajima A, Inoue E, Tanaka E, Singh G, Sato E, Hoshi D, et al Mortality and cause of death in Japanese patients with rheumatoid arthritis based on a large observational cohort. IORRA. Scand J Rheumatol. 2010;39(5):360-7.

68. Harigai M, Koike R, Miyasaka N. Pneumocystis pneumonia associated with infliximab in Japan. $\mathrm{N}$ Engl $\mathrm{J}$ Med. 2007;357(18):1874-6.

69. Sternberg SA, Wershof Schwartz A, Karunananthan S, Bergman $\mathrm{H}$, Mark Clarfield A. The identification of frailty: a systematic literature review. J Am Geriatr Soc. 2011;59(11):2129-38.

70. Fried LP, Tangen CM, Walston J, Newman AB, Hirsch C, Gottdiener J, et al. Frailty in older adults: evidence for a phenotype. J Gerontol A Biol Sci Med Sci. 2001;56(3):M146-56. 
71. Op het Veld LP, van Rossum E, Kempen GI, de Vet HC, Hajema K, Beurskens AJ. Fried phenotype of frailty: cross-sectional comparison of three frailty stages on various health domains. BMC Geriatr. 2015;15:77.

72. Newman AB, Gottdiener JS, McBurnie MA, Hirsch CH, Kop WJ, Tracy R, et al. Associations of subclinical cardiovascular disease with frailty. J Gerontol A Biol Sci Med Sci. 2001;56(3):M158-66.

73. Shlipak MG, Stehman-Breen C, Fried LF, Song X, Siscovick D, Fried LP, et al. The presence of frailty in elderly persons with chronic renal insufficiency. Am J Kidney Dis. 2004;43(5):861-7.

74. Misra D, Felson DT, Silliman RA, Nevitt M, Lewis CE, Torner J, et al. Knee osteoarthritis and frailty: findings from the Multicenter Osteoarthritis Study and osteoarthritis initiative. J Gerontol A Biol Sci Med Sci. 2015;70(3):339-44.

75. Cacciatore F, Della-Morte D, Basile C, Mazzella F, Mastrobuoni C, Salsano E, et al. Long-term mortality in frail elderly subjects with osteoarthritis. Rheumatology (Oxford). 2014;53(2):293-9.

76. Chen YM, Chen LK, Lan JL, Chen DY. Geriatric syndromes in elderly patients with rheumatoid arthritis. Rheumatology (Oxford). 2009;48(10):1261-4.

77. Yelin E, Trupin L, Wong B, Rush S. The impact of functional status and change in functional status on mortality over 18 years among persons with rheumatoid arthritis. J Rheumatol. 2002;29(9):1851-7.

78. Matcham F, Rayner L, Steer S, Hotopf M. The prevalence of depression in rheumatoid arthritis: a systematic review and metaanalysis. Rheumatology (Oxford). 2013;52(12):2136-48.

79. Stanmore EK, Oldham J, Skelton DA, O'Neill T, Pilling M, Campbell AJ, et al. Fall incidence and outcomes of falls in a prospective study of adults with rheumatoid arthritis. Arthritis Care Res (Hoboken). 2013;65(5):737-44.

80. Gomez-Vaquero C, Nolla JM, Fiter J, Ramon JM, Concustell R, Valverde $\mathbf{J}$, et al. Nutritional status in patients with rheumatoid arthritis. Jt Bone Spine. 2001;68(5):403-9.

81. Treharne GJ, Douglas KM, Iwaszko J, Panoulas VF, Hale ED, Mitton DL, et al. Polypharmacy among people with rheumatoid arthritis: the role of age, disease duration and comorbidity. Musculoskeletal Care. 2007;5(4):175-90.

82. Stavropoulos-Kalinoglou A, Metsios GS, Veldhuijzen van Zanten JJ, Nightingale P, Kitas GD, Koutedakis Y. Individualised aerobic and resistance exercise training improves cardiorespiratory fitness and reduces cardiovascular risk in patients with rheumatoid arthritis. Ann Rheum Dis. 2013;72(11):1819-25.

83. Hakkinen A, Sokka T, Kautiainen H, Kotaniemi A, Hannonen P. Sustained maintenance of exercise induced muscle strength gains and normal bone mineral density in patients with early rheumatoid arthritis: a 5 year follow up. Ann Rheum Dis. 2004;63(8):910-6.

84. Munneke M, de Jong Z, Zwinderman AH, Ronday HK, van den Ende $\mathrm{CH}$, Vliet Vlieland TP, et al. High intensity exercise or conventional exercise for patients with rheumatoid arthritis? Outcome expectations of patients, rheumatologists, and physiotherapists. Ann Rheum Dis. 2004;63(7):804-8.

85. Metsios GS, Stavropoulos-Kalinoglou A, Veldhuijzen van Zanten JJ, Nightingale P, Sandoo A, Dimitroulas T, et al. Individualised exercise improves endothelial function in patients with rheumatoid arthritis. Ann Rheum Dis. 2014;73(4):748-51.
86. Kojima T, Akishita M, Nakamura T, Nomura K, Ogawa S, Iijima $\mathrm{K}$, et al. Association of polypharmacy with fall risk among geriatric outpatients. Geriatr Gerontol Int. 2011;11(4):438-44.

87. Benetos A, Rossignol P, Cherubini A, Joly L, Grodzicki T, Rajkumar $\mathrm{C}$, et al. Polypharmacy in the aging patient: management of hypertension in octogenarians. JAMA. 2015;314(2):170-80.

88. Hajjar ER, Cafiero AC, Hanlon JT. Polypharmacy in elderly patients. Am J Geriatr Pharmacother. 2007;5(4):345-51.

89. American Geriatrics Society updated Beers Criteria for potentially inappropriate medication use in older adults. J Am Geriatr Soc. 2012;60(4):616-31.

90. Visser K, Goekoop-Ruiterman YP, de Vries-Bouwstra JK, Ronday HK, Seys PE, Kerstens PJ, et al. A matrix risk model for the prediction of rapid radiographic progression in patients with rheumatoid arthritis receiving different dynamic treatment strategies: post hoc analyses from the BeSt study. Ann Rheum Dis. 2010;69(7):1333-7.

91. Kroot EJ, de Jong BA, van Leeuwen MA, Swinkels H, van den Hoogen FH, van't Hof M, et al. The prognostic value of anticyclic citrullinated peptide antibody in patients with recent-onset rheumatoid arthritis. Arthritis Rheum. 2000;43(8):1831-5.

92. Smolen JS, Van Der Heijde DM, St Clair EW, Emery P, Bathon $\mathrm{JM}$, Keystone E, et al. Predictors of joint damage in patients with early rheumatoid arthritis treated with high-dose methotrexate with or without concomitant infliximab: results from the ASPIRE trial. Arthritis Rheum. 2006;54(3):702-10.

93. Welsing PM, Landewe RB, van Riel PL, Boers M, van Gestel $\mathrm{AM}$, van der Linden $\mathrm{S}$, et al. The relationship between disease activity and radiologic progression in patients with rheumatoid arthritis: a longitudinal analysis. Arthritis Rheum. 2004;50(7):2082-93.

94. Landewe R, van der Heijde D, Klareskog L, van Vollenhoven R, Fatenejad S. Disconnect between inflammation and joint destruction after treatment with etanercept plus methotrexate: results from the trial of etanercept and methotrexate with radiographic and patient outcomes. Arthritis Rheum. 2006;54(10):3119-25.

95. Emery P, Breedveld F, van der Heijde D, Ferraccioli G, Dougados M, Robertson D, et al. Two-year clinical and radiographic results with combination etanercept-methotrexate therapy versus monotherapy in early rheumatoid arthritis: a two-year, double-blind, randomized study. Arthritis Rheum. 2010;62(3):674-82.

96. Radovits BJ, Fransen J, Eijsbouts A, van Riel PL, Laan RF. Missed opportunities in the treatment of elderly patients with rheumatoid arthritis. Rheumatology (Oxford). 2009;48(8):906-10.

97. Schmajuk G, Schneeweiss S, Katz JN, Weinblatt ME, Setoguchi $\mathrm{S}$, Avorn J, et al. Treatment of older adult patients diagnosed with rheumatoid arthritis: improved but not optimal. Arthritis Rheum. 2007;57(6):928-34.

98. Zhang J, Xie F, Delzell E, Yun H, Lewis JD, Haynes K, et al. Impact of biologic agents with and without concomitant methotrexate and at reduced doses in older rheumatoid arthritis patients. Arthritis Care Res (Hoboken). 2015;67(5):624-32.

99. Burmester GR, Kivitz AJ, Kupper H, Arulmani U, Florentinus S, Goss SL, et al. Efficacy and safety of ascending methotrexate dose in combination with adalimumab: the randomised CONCERTO trial. Ann Rheum Dis. 2015;74(6):1037-44. 